\title{
PENERAPAN METODE BERMAIN PERAN MAKRO TERHADAP KEMAMPUAN BERBICARA
}

\author{
Nirwana \\ STKIP Kusuma Negara Jakarta \\ email: nirwana@stkipkusumanegara.ac.id
}

\begin{abstract}
Effect of role playing macro methods on children's speaking ability in group B in Nurul Rohmah Bekasi. This research is motivated by the lack of ability to speak children. This is because the method used in the learning process is more likely to use conventional methods. The selection of methods to role playing macro so that children can be motivated and interested in learning and can stimulate the ability to speak children. The population in this study were all children of group B in kindergarten Nurul Rohmah while the study sample was B3 group 11 children for the experimental group and B1 group 11 children for the control group. Data collection techniques through test techniques, and observation. Data analysis techniques used were descriptive statistical analysis and nonparametric statistical analysis. Based on the results of the Wilcoxon test calculation, the calculated $T$ value is 66 and $T$ table 11 then the results obtained T count (66)> T table (11) HI is accepted and Ho is rejected means that there is an effect of role playing macro methods on children's speaking ability. Whereas the calculated $Z$ value obtained is 2.93 and 1.645 table $Z$ then the result of $Z$ arithmetic (2.93) $>Z$ table (1.645) HI is accepted and Ho is rejected which means that there is an effect of role playing macro method on children's speaking ability. These results indicate that there is a change in the value of the child's speaking ability before and after getting learning based on the role playing macro method.
\end{abstract}

Keywords: early childhood, role playing macro, speaking ability

\begin{abstract}
Abstrak
Pengaruh metode bermain peran makro terhadap kemampuan berbicara anak pada kelompok B di KanakKanak Nurul Rohmah Bekasi. Penelitian ini dilatarbelakangi oleh kurangnya kemampuan berbicara anak. Hal ini dikarenakan metode yang digunakan dalam proses pembelajaran lebih cenderung menggunakan metode konvensional. Adapun pemilihan metode bermain peran makro agar anak dapat termotivasi dan tertarik untuk belajar dan dapat menstimulasi kemampuan berbicara anak. Populasi dalam penelitian ini adalah seluruh anak kelompok B di Taman Kanak-kanak Nurul Rohmah sedangkan sampel penelitian adalah kelompok B3 11 anak untuk kelompok eksperimen dan kelompok B1 11 anak untuk kelompok kontrol. Tehnik pengumpulan data melalui tehnik tes, dan observasi. Tehnik analisis data yang digunakan adalah analisis statistik deskriptif dan analisis statistik nonparametrik. Berdasarkan hasil perhitungan uji Wilcoxon, Adapun nilai T hitung yang diperoleh yaitu 66 dan $\mathrm{T}$ tabel 11 maka diperoleh hasil T hitung (66) $>\mathrm{T}$ tabel (11) $\mathrm{H}_{1}$ diterima dan Ho ditolak artinya ada pengaruh metode bermain peran makro terhadap kemampuan berbicara anak. Sedangkan nilai $Z$ hitung yang diperoleh yaitu 2,93 dan $Z$ tabel 1,645 maka diperoleh hasil $\mathrm{Z}$ hitung $(2,93)>\mathrm{Z}$ tabel $(1,645) \mathrm{H}_{1}$ diterima dan Ho ditolak yang artinya ada pengaruh metode bermain peran makro terhadap kemampuan berbicara anak. Hasil ini menunjukkan bahwa terjadi perubahan nilai pada kemampuan berbicara anak sebelum dan sesudah mendapatkan pembelajaran berdasarkan metode bermain peran makro.
\end{abstract}

Kata kunci: anak usia dini, bermain peran, berbicara 


\section{PENDAHULUAN}

Pendidikan anak usia dini merupakan masa yang paling penting untuk mendapatkan stimulasi agar dapat berkembang dengan optimal. Salah satu tugas perkembangan yang perlu mendapatkan perhatian pagi para pendidik adalah perkembangan bahasa anak. Perkembangan bahasa merupakan salah satu kemampuan dasar yang dimiliki anak. Kemampuan bahasa memerlukan beberapa kemampuan yaitu berbicara, menyimak, membaca, menulis, dan menggunakan bahasa isyarat. Berbicara adalah bentuk bahasa yang menggunakan artikulasi atau kata-kata yang digunakan untuk menyampaikan maksud.

Kemampuan berbicara anak sering mengalami hambatan misalnya anak kurang dapat merespon dengan baik lawan bicara sehingga kurang mampu mengungkapkan kata-kata dengan baik. Bahkan ada sebagian anak yang tidak mampu mengajukan pertanyaan dengan baik. Rendahnya kemampuan berbicara pada anak pada umumnya disebabkan anak hanya duduk, diam, dan mendengarkan, tidak hanya itu sebagian anak merasa takut dan tidak percaya diri untuk tampil berbicara di depan kelas selama proses pembelajaran.

Berbagai kegiatan yang dapat diterapkan untuk menstimulasi perkembangan berbicara anak di antaranya adalah bermain peran makro. Dalam bermain peran makro ini, anak dapat terlibat aktif untuk mengembangkan keterampilan sosial dan keterampilan berbicara anak melalui tokoh yang dipilih untuk diperankan. Hal ini sejalan dengan teori Vigotsky (Latif dkk: 2013) yang menyatakan bahwa bermain merupakan cara anak berfikir dan memecahkan masalahnya. Dengan demikian, anak yang bermain adalah anak yang menyerap berbagai hal baru di sekitarnya seperti kosakata. Pemilihan jenis permainan yang cocok sesuai dengan perkembangan anak menjadi penting agar pesan edukatif dari permainan dapat ditangkap anak dengan mudah dan menyenangkan. Jenis permainan yang dapat dipilih untuk mengembangkan kemampuan berbicara pada anak adalah bermain peran. Sehubungan dengan hal tersebut, peneliti melakukan eksperimen dengan menerapkan metode bermain peran makro terhadap kemampuan berbicara pada anak.

Berdasarkan latar belakang di atas, maka rumusan masalah dalam penelitian ini yaitu:

1. Bagaimana gambaran kemampuan berbicara anak yang diberi perlakuan metode bermain peran makro pada anak kelompok B di TK Nurul Rohmah Bekasi?

2. Bagaimana gambaran kemampuan berbicara anak yang diberi perlakuan metode bermain peran makro pada anak kelompok B di di TK Nurul Rohmah Bekasi?

3. Apakah ada pengaruh metode bermain peran makro terhadap kemampuan berbicara antara kelompok eksperimen dan kelompok kontrol di di TK Nurul Rohmah Bekasi?

Berdasarkan rumusan masalah di atas maka tujuan dalam penelitian ini yaitu untuk mengetahui:

1. Untuk mengetahui bagaimana gambaran kemampuan berbicara anak yang diberi perlakuan metode bermain peran makro pada anak kelompok B di TK Nurul Rohmah Bekasi

2. Untuk mengetahui bagaimana gambaran kemampuan berbicara anak yang diberi perlakuan metode bermain peran makro pada anak kelompok B di TK Nurul Rohmah Bekasi.

3. Untuk mengetahui pengaruh metode bermain peran makro terhadap kemampuan berbicara antara kelompok eksperimen dan kelompok kontrol di TK Nurul Rohmah Bekasi. 


\section{KAJIAN LITERATUR Bermain Peran}

Bermain peran menjadi suatu kegiatan yang menjadikan anak sebagai pemeran dalam suatu peristiwa yang dapat mengembangkan daya imajinasi anak. Kegiatan bermain peran (role playing) sering menjadi pilihan yang menarik untuk diterapkan oleh guru. Sebab kegiatan bermain peran dianggap cukup efektif. Selain itu, kegiatan bermain peran juga dirasa sangat menyenangkan bagi anak.

Menurut Tarigan (1993:177) bahwa bermain peran lebih sederhana dalam segala hal dibandingkan dengan bermain drama. Pada dasarnya bermain peran adalah bagian dari bermain drama sehingga cakupan pementasannya lebih sederhana, yaitu pemeain hanya memerankan tokoh dalam naskahdrama. Walaupun ketika memerankan tokoh didukung dengan unsur-unsur yang lain namun bermain peran hanya sebatas memerankan tokoh dalama naskah lengkap dengan dialog dan itu sudah cukup. Seorang pemain, pemeran atau aktor dalam kegiatan bermain peran bertugas menghidupkan tokoh-tokoh dalam drama yang digambarkan penulisnya lewat apa yang diucapkan dalam bentuk dialog. Pemeran harus menafsirkan watak tertentu yang diinginkan oleh pengarangnya. Pemeran tidak hanya mengucapkan apa yang ditulis dalam naskah drama, tetapi juga harus "berbuat" sesuai dengan gambaran watak yang diperankan. Sejalan dengan itu, Erikson \& vygotsky (Mutiah: 2010) menyatakan bahwa bermain peran merupakan permainan simbolis, purapura, make believe, imajinasi, fantasi atau main drama. Permainan ini penting dalam perkembangan sosial, kognisi, serta emosi anak pada usia 3 sampai 6 tahun.

Bermain peran dipahami sebagai bentuk permainan yang memerankan karakter seseorang dalam hubungannya dengan ide cerita. Pemain bertanggung jawab untuk berakting sesuai dengan peran yang dimainkan, baik melalui acting benar-benar maupun melalui proses membuat keputusan secara struktural atau pengembangan karakter Menurut Soetrisman (1981:1) bermain peran merupakan suatu pementasan atau penyajian dari suatu naskah yang ditulis dan dihafalkan yang dimainkan di hadapan penonton. Sejalan dengan Soetrisman, Wiyanto (2002:1) berpendapat bahwa bermain peran adalah pementasan yang menonjolkan percakapan (dialog) dan gerakgerik para pemain di panggung. Percakapan dan gerak-gerik itu memeragakan cerita yang ditulis dalam naskah.

Nugraha \& Rachmawati (2011) mengemukakan bahwa bermain peran merupakan permainan yang dilakukan melalui peranan tokoh-tokoh, benda-benda maupun tumbuhan dan binatang. Permainan ini dilakukan dengan menggunakan daya imajinasi, empati, serta kreatifitas yang dimiliki oleh anak. Anak bebas menjadi tokoh maupun sesuatu yang diinginkannya.

Dari pendapat di atas dapat disimpulkan bahwa bermain peran merupakan kegiatan bermain sambil belajar dimana anak bebas berimajinasi, bebas menjadi tokoh ataupun sesuatu yang diinginkannya, dan anak akan belajar memahami orang lain sesuai peran yang telah di perankan.

\section{Jenis Bermain Peran}

Erikson membagi dua jenis main peran sebagaimana yang dikemukakan (Latif dkk: 2013) yaitu:

1) Main peran mikro; bermain peran mikro adalah bermain peran dengan bendabenda kecil dimana benda tersebut menyimbolkan sesuatu misalnya ketika anak bermain dengan balok dan mendorong beberapa balok sampai bernyanyi naik kerata api.

2) Bermain peran makro; bermain peran makro adalah suatu kegiatan yang dilakukan dengan memerankan tokohtokoh tertentu dengan menggunakan alat bantu yang sesuai dengan peran yang ditokohkan seperti sebagai dokter, maka 
anak akan berpura-pura memakai baju putih seperti dokter berikut dengan stetoskopnya. Bermain peran makro atau besar lebih terarah kepada bermain sosiodrama dengan melibatkan banyak anak dan menggunakan ruangan (space) yang cukup luas.

Pendapat lain dikemukakan oleh Khoiruddin (2010) bahwa terdapat dua jenis metode bermain peran yaitu:

1) Metode bermain peran makro; metode bermain peran makro yaitu bermain peran yang sesungguhnya dengan alatalat main berukuran sesungguhnya. Anak dapat menggunakannya untuk menciptakan dan memainkan peranperan, misalnya bermain peran profesi dokter, maka alat yang digunakan stetoskop, replika jarum suntik, buku resep dan pulpen.

2) Metode bermain peran mikro; metode bermain peran mikro yaitu kegiatan bermain peran dengan menggunakan bahan-bahan main berukuran kecil seperti rumah boneka lengkap dengan perabotannya dan orang-orangannya sehingga anak dapat memainkannya.

\section{Manfaat Bermain Peran}

Beberapa manfaat dalam bermain peran yang dikemukakan Madyawati (2016) yaitu:

1) Mengembangkan kepercayaan diri pada anak; dengan berpura-pura menjadi apapun yang anak inginkan, dapat membuat anak merasakan sensasi menjadi karakter-karakter tadi sehingga dapat meningkatkan kepercayaan dirinya.

2) Mengembangkan kemampuan berbahasa; pengertian perkembangan bahasa anak usia dini adalah salah satu aspek dari tahapan perkembangan anak yang diekspresikan melalui pemikiran anak dengan menggunakan kata-kata yang menandai meningkatnya kemampuan dan kreativitas anak sesuai dengan tahap perkembangannya.
3) Membuka kesempatan untuk memecahkan masalah; pada situasi tertentu saat bermain peran, pikiran anak akan terlatih untuk menemukan solusi jika ada masalah yang terjadi.

4) Membangun kemampuan sosial dan empati; anak sedang menempatkan dirinya dalam pengalaman menjadi orang lain. menghidupkan kembali sebuah adegan dapat membantu anak menghargai perasaan orang lain sehingga dapat membantu mengembangkan empatinya.

5) Memberikan anak pandangan positif; anak memiliki imajinasi yang tidak terbatas. Bermain peran dapat membantu anak berusaha mencapai mimpi dan citacitanya.

\section{Tujuan Bermain Peran}

Mulyasa (2012) mengemukakan bahwa bermain peran di Taman Kanak-Kanak bertujuan untuk memecahkan masalah meralui peragaan, serta langkah-langkah identifikasi masalah, analisis, pemeranan, dan diskusi. Selain itu, Catron \& Allen (Mutiah: 2010) menyatakan bahwa bermain dapat mendukung perkembangan sosialisasi anak dalam hal berinteraksi sosial, bekerja sama, menghemat sumber daya serta peduli terhadap orang lain. Bermain peran adalah agar anak dapat mengembangkan keterampilan dan sikap dalam memecahkan masalah yang dihadapinya melalui eksplorasi perasaan-perasaannya. Bermain peran juga bertujuan melatih kemampuan berbicara, melatih daya konsentrasi anak.

\section{Kemampuan Berbicara}

Kemampuan berbicara merupakan kemampuan mengucapkan bunyi-bunyi artikulasi atau mengucapkan kata-kata untuk mengekspresikan, menyatakan, menyampaikan pikiran, gagasan, dan perasaan. Pendengar menerima informasi melalui rangkaian nada, tekanan dan penempatan persediaan (juncrute) jika 
komunikasi berlangsung secara tatap muka, ditambah lagi dengan gerakan tangan dan air muka (mimik) pembicara.

Menurut Syamsiah (2008: 10) "berbicara merupakan keterampilan mengucapkan bunyi-bunyi artikulasi atau kata-kata guna mengekspresikan, menyatakan serta menyampaikan pikiran, gagasan dan perasaan sacara lisan”. Pendapat yang tidak jauh berbeda dikemukakan oleh Hurlock (1978: 176) "belajar berbicara mencakup tiga proses terpisah, tetapi saling berhubungan satu sama lain, yaitu mengucapkan kata, membangun kosakata, dan membentuk kalimat".

Madyawati (2016) mengemukakan berbicara artinya melahirkan pendapat dengan perkataan. Berbicara yaitu menyampaikan informasi melalui bunyi bahasa. Berbicara dianggap sebagai kebutuhan pokok bagi masyarakat karena dengan berbicara seorang dapat menyampaikan dan mengkomunikasikan segala isi dan gagasan batin.

Adapun indikator kemampuan berbicara pada anak usia 5-6 tahun yang terdapat dalam permen 146 tahun 2014 yaitu: 1) bertanya dengan menggunakan lebih dari dua kata Tanya, 2) mengungkapkan keinginan, perasaan, dan pendapat dengan kalimat sederhana dalam berbicara dengan anak atau orang dewasa, dan 4) menggunakan kalimat pendek untuk berinteraksi dengan anak atau orang dewasa untuk menyatakan apa yang dilihat dan dirasa.

\section{Tahapan Kemampuan Berbicara}

Tahapan-tahapan perkembangan awal ujaran pada anak adalah, menurut Pateda (Suhartono, 2005) yaitu tahap penamaan, tahap telegrafis dan tahap transformasional. Tahapan tersebut dapat diuraikan sebagai berikut:

1) Tahap penamaan; pada tahap ini anak mengasosiasikan bunyi-bunyi yang pernah didengarnya dengan benda, peristiwa, situasi, kegiatan dan sebagainya yang pernah dikenal melalui lingkungannya.

2) Tahap telegrafis; pada tahap ini anak mampu menyampaikan pesan yang diinginkannya dalam bentuk ukuran bunyi yang berwujud dua atau tiga kata. Anak menggunakan dua atau tiga kata untuk mengganti kalimat yang berisi maksud tertentu dan ada hubungannya dengan makna, ujaran tersebut sangat singkat dan padat.

3) Tahap transformasional; pada tahap ini anak sudah mulai memberanikan diri untuk bertanya, menyuruh, menyanggah dan menginformasikan sesuatu. Pada tahap ini anak sudah mulaimentransformasikan idenya kepada orang lain dalam bentuk kalimat yang beragam. Berbagai kegiatan anak aktivitasnya dikomunikasikan atau diujarkan melalui kalimat-kalimat, yang termasuk pada tahap ini yaitu anak berumur lima tahun.

Berdasarkan tahapan-tahapan diatas maka dapat disimpulkan bahwa tahapan berbicara anak yang berada pada rentang usia 5-6 tahun berada pada tahap transformasional. Pada tahap tersebut anak sudah dapat bertanya, menyuruh, menyanggah, menginformasikan sesuatu serta berani mentransformasikan idenya kepada orang lain dalam bentuk kalimat yang beragam.

\section{METODE PENELITIAN}

Pendekatan penelitian ini adalah pendekatan kuantitatif. Dipilihnya pendekatan ini karena secara epistemologi penelitian ini memadukan dua sumber ilmu, yaitu (a) pemikiran rasional, dan (b) data empiris. Pemikiran rasional berupa kerangka berpikir menghasilkan hipotesis, selanjutnya diverifikasi dengan data empiris. Dengan demikian penelitian ini mengikuti siklus logico, hypothetico, verifikatif (Suradika dan Wicaksono, 2019: 
33). Sugiyono (2016: 14) mengemukakan "untuk mengumpulkan data digunakan instrument penelitian". Data yang telah terkumpul selanjutnya dianalisis secara kuantitatif dengan menggunakan statistik desktiptif sehingga dapat disimpulkan hipotesis yang dirumuskan terbukti atau tidak.

Jenis penelitian yang digunakan disini adalah jenis penelitian Quasi Eksperiment atau eksperimen semu. Metode mempunyai kelompok kontrol, tetapi tidak berfungsi sepenuhnya untuk mengontrol variabelvariabel luar yang mempengaruhi pelaksanaan eksperimen. Metode eksperimen semu ini digunakan untuk mengetahui perkembangan kemampuan berbicara anak yang diberi perlakuan bermain peran makro. Penggunaan jenis penelitian ini berdasarkan sifat populasi, yakni anak didik yang tidak tetap dan berfariasi.

Penelitian ini mengkaji dua varibel, yaitu pengaruh bermain peran makro sebagai variabel bebas atau yang mempengaruhi dan kemampuan berbicara sebagai variabel terikat atau yang dipengaruhi. Desain penelitian yang digunakan yaitu Nonequivalent Control Group Design. Di dalam desain ini, penelitian menggunakan satu kelompok eksperimen dengan kelompok pembanding dengan diawali sebuah tes awal (pretest) yang diberikan kepada kedua kelompok, kemudian diberi perlakuan (treatment). Penelitian kemudian diakhiri dengan sebuah tes akhir (posttest) yang diberikan kepada kedua kelompok. Desain dalam penelitian ini digambarkan, sebagai berikut:

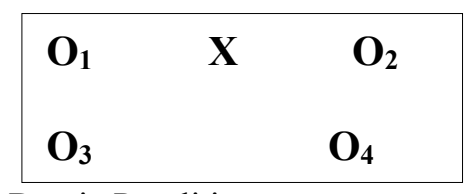

Gambar 1.Desain Penelitian

Keterangan:
O1 dan O3: Pengukuran pertama (awal) sebelum subyek diberikan perlakuan bermain peran makro.

$\mathbf{X}$ : Treatment atau perlakuan (bermain peran makro).

O2: Pengukuran kedua setelah subjek diberikan metode bermain peran makro.

O4: Pengukuran yang tidak diberi perlakuan metode bermain peran makro.

\section{HASIL DAN PEMBAHASAN}

Dalam pengambilan keputusan jika $T$ hitung $<\mathrm{T}$ tabel $=$ Ho diterima dan $\mathrm{H}_{1}$ ditolak artinya tidak ada pengaruh metode bermain peran makro terhadap kemampuan berbicara anak di kelompok eksperimen TK Nurul Rohmah. Jika $\mathrm{T}$ hitung $>\mathrm{T}$ tabel $=$ Ho di tolak $\mathrm{H}_{1}$ diterima artinya ada pengaruh metode bermain peran makro terhadap kemampuan berbicara anak di kelompok kontrol TK Nurul Rohmah. Jika Z hitung < $\mathrm{Z}$ tabel $=$ Ho diterima $\mathrm{H}_{1}$ ditolak artinya tidak ada pengaruh metode bermain peran makroterhadap kemampuan berbicara anak di kelompok eksperimen TK Nurul Rohmah, jika $\mathrm{Z}$ hitung $>\mathrm{Z}$ tabel $=$ Ho ditolak $\mathrm{H}_{1}$ diterima artinya ada pengaruh metode bermain peran makro terhadap kemampuan berbicara anak di kelompok kontrol TK Nurul Rohmah.

Adapun nilai $\mathrm{T}$ hitung yang diperoleh yaitu 66 dan $\mathrm{T}$ tabel 11 maka diperoleh hasil $\mathrm{T}$ hitung (66) $>\mathrm{T}$ tabel (11) $\mathrm{H}_{1}$ diterima dan Ho ditolak artinya ada pengaruh metode bermain peran makro terhadap kemampuan berbicara anak. Sedangkan nilai $\mathrm{Z}$ hitung yang diperoleh yaitu 2,93 dan $Z$ tabel 1,645 maka diperoleh hasil $\mathrm{Z}$ hitung $(2,93)>\mathrm{Z}$ tabel $(1,645) \mathrm{H}_{1}$ diterima dan Ho ditolak yang artinya ada pengaruh metode bermain peran makro terhadap kemampuan berbicaraanak. Hasil ini menunjukkan bahwa terjadi perubahan nilai pada kemampuan berbicara anak sebelum dan sesudah mendapatkan pembelajaran berdasarkan metode bermain peran makro. Hal tersebut menunjukkan bahwa kemampuan berbicara anak yang menerima perlakuan berupa metode bermain peran makro lebih baik 
dibandingkan sebelum diberikan perlakuan. Berdasarkan uraian diatas maka dapat disimpulkan bahwa penerapan metode bermain peran makro berpengaruh terhadap kemampuan berbicara anak.

Berdasarkan hasil perhitungan uji Wilcoxon terdapat perbedaan yang signifikan antara kemampuan berbicara anak yang mengikuti pembelajaran dengan metode bermain bermain peran dengan kelompok anak yang mengikuti pembelajaran dengan metode konvensional. Skor kemampuan berbicara anak bagi kelompok anak yang mengikuti pembelajaran dengan metode bermain bermain peran lebih tinggi dibandingkan dengan rata-rata hasil skor kemampuan berbicara bagi kelompok anak yang mengikuti pembelajaran dengan metode konvensional.

Hal ini disebabkan karena metode bermain peran makro anak terlibat secara langsung dalam kegiatan dimana mereka memiliki memainkan perannya masingmasing (Latif dkk: 2013). Bermain peran makro adalah suatu kegiatan yang dilakukan dengan memerankan tokoh-tokoh tertentu dengan menggunakan alat bantu yang sesuai dengan peran yang ditokohkan seperti sebagai dokter, maka anak akan berpurapura memakai baju putih seperti dokter berikut dengan stetoskopnya. Bermain peran makro atau besar lebih terarah kepada bermain sosiodrama dengan melibatkan banyak anak dan menggunakan ruangan (space) yang cukup luas.

Pada saat anak bermain peran makro secara tidak langsung anak-anak terlibat dalam percakapan tanya jawab saat terlibat dalam peran. Kemampuan mereka merangkai kata secara spontan nampak terdengar dengan baik dan mudah dipahami.

Dengan demikian dapat diketahui ada beberapa hal yang menyebabkan perbedaan skor kemampuan berbicara anak antara kelompok yang mengikuti pembelajaran dengan metode bermain peran makro dengan pembelajaran dengan metode konvensional, dimana skor kemampuan berbicara anak yang mengikuti pembelajaran dengan metode bermain peran makrolebih tinggi dari pada kelompok anak yang mengikuti pembelajaran konvensional.

\section{KESIMPULAN}

Berdasarkan hasil analisis dan uji statistik pada pembahasan sebelumnya, maka dapat ditarik kesimpulan sebagai berikut :

1. Hasil kemampuan berbicara bagi kelompok anak yang mengikuti pembelajaran dengan metode bermain peran makro termasuk kategori tinggi.

2. Hasil kemampuan berbicara bagi kelompok anak yang mengikuti pembelajaran konvensional termasuk kategori sedang.

3. Terdapat pengaruh efektif penerapan metode bermain peran makro terhadap kemampuan motorik halus anak.

\section{REFERENSI}

Harlock, Elizabeth, B. 1978. Perkembangan Anak. Jilid 1. Terjemahan oleh Meitasari Tjandrasa dan Muhlichah Zarkasih. Jakarta: Erlangga.

Madyawati, Lilis. 2016. Strategi Pengembangan Bahasa Pada Anak. Jakarta: Kencana.

Moeslichatoen. 2004. Metode Pengajaran di Taman Kanak-Kanak. Jakarta: Rineka Cipta.

Mutiah, Diana. 2010. Psikologi Bermain Anak Usia Dini. Jakarta: Kencana.

Mulyasa, H.E. 2012. Manajemen PAUD. Bandung: PT. Remaja Rosda karya.

Peraturan Menteri Pendidikan Nasional Indonesia Nomor 146 Tahun 2014 tentang 
Standar Pendidikan Anak Usia Dini. Jakarta. Departemen Pendidikan Nasional.

Rachmawati \& Nugraha. 2011. Strategi Pengembangan Kreativitas Pada Anak Usia Taman Kanak-Kanak. Jakarta: Katalog Dalam Terbitan.

Sugiyono. 2010. Metode Penelitian Pendidikan Pendekatan Kuantitatif, Kualitatif, dan R\&D. Bandung: Alfabeta.
Syamsiah. 2008. Model pembelajaran. Jakarta: PT. Grasindo.

Suhartono. 2015. Teknik Pembelajaran Bahasa dan Sastra. Surabaya Penerbit

Suradika, Agus, dan Wicaksono. 2019. Metodologi Penelitian. Jakarta: UM Jakarta Press.

Yaumi, Muhammad \& Nurdin Ibrahim. 2013. Kecerdasan Jamak. Jakarta: Kencana 